Article

\title{
Integrated Fire Management as a Renewing Agent of Native Vegetation and Inhibitor of Invasive Plants in Vereda Habitats: Diagnosis by Remotely Piloted Aircraft Systems
}

\author{
Jéssika Cristina Nascente ${ }^{1}$, Manuel Eduardo Ferreira ${ }^{2}$ (D) and Gustavo Manzon Nunes ${ }^{1, *}$
}

1 LabSensoR-Remote Sensing and Geotechnologies Laboratory, Postgraduate Program in Forest and Environmental Sciences, Faculty of Forestry Engineering, Cuiabá Campus, Federal University of Mato Grosso, Av. Fernando Corrêa da Costa, 2367. Boa Esperança, Cuiabá 78060-900, MT, Brazil; jessikanascente@sema.mt.gov.br

2 LAPIG-Image Processing and GIS Laboratory, Institute of Socio-Environmental Studies, Samambaia Campus, Federal University of Goiás, Av. Esperança s/n, Goiânia 74690-900, GO, Brazil; manuel@ufg.br

* Correspondence: gustavo.nunes@ufmt.br

check for updates

Citation: Nascente, J.C.; Ferreira, M.E.; Nunes, G.M. Integrated Fire Management as a Renewing Agent of Native Vegetation and Inhibitor of Invasive Plants in Vereda Habitats: Diagnosis by Remotely Piloted Aircraft Systems. Remote Sens. 2022, 14, 1040. https://doi.org/10.3390/ rs14041040

Academic Editor: Luis A. Ruiz

Received: 23 December 2021

Accepted: 16 February 2022

Published: 21 February 2022

Publisher's Note: MDPI stays neutral with regard to jurisdictional claims in published maps and institutional affiliations.

Copyright: () 2022 by the authors Licensee MDPI, Basel, Switzerland. This article is an open access article distributed under the terms and conditions of the Creative Commons Attribution (CC BY) license (https:// creativecommons.org/licenses/by/ $4.0 /)$.

\begin{abstract}
The Cerrado biome is being gradually reduced. Remote sensing has been widely used to investigate spatio-temporal changes in the landscape, which are frequently limited to mapping with orbital sensors, while the Remotely Piloted Aircraft System (RPAS) proved to be advantageous in terms of spatial resolution and the application of advanced digital processing techniques. In this study, we investigated a vereda (humid area) of a conservation unit in the state of Mato Grosso, Brazil. Object-Based Image Analysis (OBIA) was applied to images obtained by RPAS to distinguish the phytophysiognomies of plant strata from the vereda and to diagnose the recovery of native and invasive vegetation after prescribed burning. The study was carried out in the following five stages: biomass collection; quality analysis of the land cover; phytosociological survey; collection of control points using a GNSS receiver (type L1/L2); and the capture of aerial images with an RGB camera coupled to a DJI Phantom 4 Pro, which was performed through overflights in three different periods. Object-Based Image Analysis was subsequently performed using the Nearest Neighbor classifier combined with Feature Space Optimization, obtaining classifications with accuracy and Kappa indexes greater than $80 \%$ and 0.80 , respectively. The results of image processing allowed us to infer that fire acted as a renewing agent for native vegetation and as an inhibiting agent for invasive vegetation. The classification analyses combined with the phytosociological analysis allowed us to infer that the vereda is in the process of maturation. Therefore, the study demonstrated the potential of data obtained by RPAS for the diagnosis and analysis of vegetation dynamics in small wetlands submitted to Integrated Fire Management (IFM).
\end{abstract}

Keywords: RPAS; wetlands; OBIA; Dicranopteris flexuosa; Cerrado

\section{Introduction}

Invasion by exotic species in conservation units (CUs) is an old problem, being highlighted as a causal agent of the decline in diversity [1]. The term "encroachment" applies when a given exotic species begins to stimulate notable ecological or economic consequences [2], with its distribution occurring in an introduced or accidental manner; in other cases, it applies to a native species with increased density and geographic distribution, being recurrent among trees and shrubs on pastures [3].

Fully protected CUs should be treated with greater caution, given the functionality of ensuring the perpetuity of natural refuges. Thus, in cases of biological invasion, permanent eradication/control within and around protected areas is mandatory, as the anthropization of surrounding areas favors the installation of invasive exotic species [1]. 
The occurrence of invasion in environments of fully protected CUs has been increasingly common, such as by the fern Dicranopteris flexuosa, which was already observed in the Desterro Environmental Conservation Unit, Florianópolis-SC [4]; in the Panga Ecological Station, Uberlândia-MG [5]; and in the Rio Doce State Park and Caratinga Biological Station, Belo Horizonte-MG [6].

Although pteridophytes (e.g., fern) are not endemic to Brazil [7], D. flexuosa is widely distributed throughout Tropical America, covering almost all Brazilian states [8]. In general, they occupy open areas and interior forests, particularly occupying wetter soils and altered areas $[4,5,8]$.

Environmental conditions that are favorable for the propagation of the fern, such as a moist soil and edges of gallery forests, coincide with some ecological characteristics of the vereda environments, making these places susceptible to its occupation.

These habitats are conditioned to water table outcropping and are of great importance for the maintenance of the Cerrado fauna, as the alternation between wet and dry seasons promotes the adaptation of individuals and endemism [9], thus being implemented as a Permanent Preservation Area-PPA [10].

Currently, the veredas of the Chapada dos Guimarães National Park (PARNA, acronym in Portuguese for National Park) undergo prescribed burning as a technique for maintaining the vegetation and controlling the presence of the pteridophyte Dicranopteris flexuosa (fern).

In view of the maintenance, control, and renewal of plant species in Cerrado environments, Integrated Fire Management (IFM) acts as an inference strategy for ecological attributes and social aspects in the modification of the landscape for territorial management.

Through research, it was found that there were no studies with experimental burning in the environments of veredas to quantify its actual impact, nor a subsidy for the application of fire management techniques, since the research was carried out after accidental fires [11].

On the other hand, the use of remote sensing (RS) for the analysis of vegetation cover has become a strategic approach to quantify forest production by predicting the volume of wood and biomass in native forests [12] and forest plantations [13], as well as by obtaining the dendrometric characteristics of these areas [14].

In terms of conservation, the application of RS stands out for the discrimination of phytophysiognomies in flooded areas [15], monitoring and protection of habitats [16], and mapping of forest fire scars [12,17], among other applications.

Regarding mapping using Digital Image Processing techniques, classifiers that analyze images 'pixel-by-pixel' or by 'regions' are used, and in both cases; they can be processed using supervision or not. While 'pixel-by-pixel' classifiers use statistical and probabilistic models, the 'region' classifiers, which are used in the method of Object-Based Image Analysis (OBIA), depend on the creation of objects, as well as being based on the Nearest Neighbor rule, fuzzy logic [18], descriptors [16], machine learning algorithms [19], and decision trees [15], among other methodological frameworks.

In this context, when observing the Cerrado as a whole, the distinction of the vereda environment is more complex, since studies of high spatial resolution remote sensing imagery (orbital images) reached an impasse in the distinction between veredas and other riverside formations, mainly due to the similarity of the spectral signature of the objects of analysis [20].

Thus, Remotely Piloted Aircrafts (RPA) are a valuable tool, being considered more advantageous when compared to traditional and manned airborne platforms for presenting a lower cost for the acquisition of data with high spatial and temporal resolution without offering risks to the pilot if in adverse conditions [21,22].

Therefore, the aim of this paper is to use Remotely Piloted Aircraft System (RPAS) technologies (ground control station, payloads, communication systems between the ground station and the aircraft, and photogrammetry software) to distinguish plant strata belonging to phytophysiognomies of the Cerrado and the vereda and to diagnose the recovery of native shrubby/herbaceous vegetation and invasive fern after the influence of fire under conditions of prescribed burning. 
RPAS technologies are tools with adequate temporal coverage and spatial resolution to monitor dynamic processes and vegetation anomalies at a local scale due to their flexibility for acquiring data repeatedly, thus filling gaps in field research and orbital platform systems. The use of images with very high spatial resolution and low temporal resolution would enable us to evaluate the effectiveness of the actions of IFM during all stages of vegetation regeneration in the area of the vereda, as well as to investigate the spatial variation of the plant community composition.

\section{Materials and Methods}

\subsection{Study Area}

The study was carried out in a wetland area of 20 ha with savanna formations of vereda in the conservation unit (UC) of the Chapada dos Guimarães National Park (PNCG, acronym in Portuguese), which is partially located between the municipalities of Cuiabá and Chapada dos Guimarães in the state of Mato Grosso [23] (Figure 1).

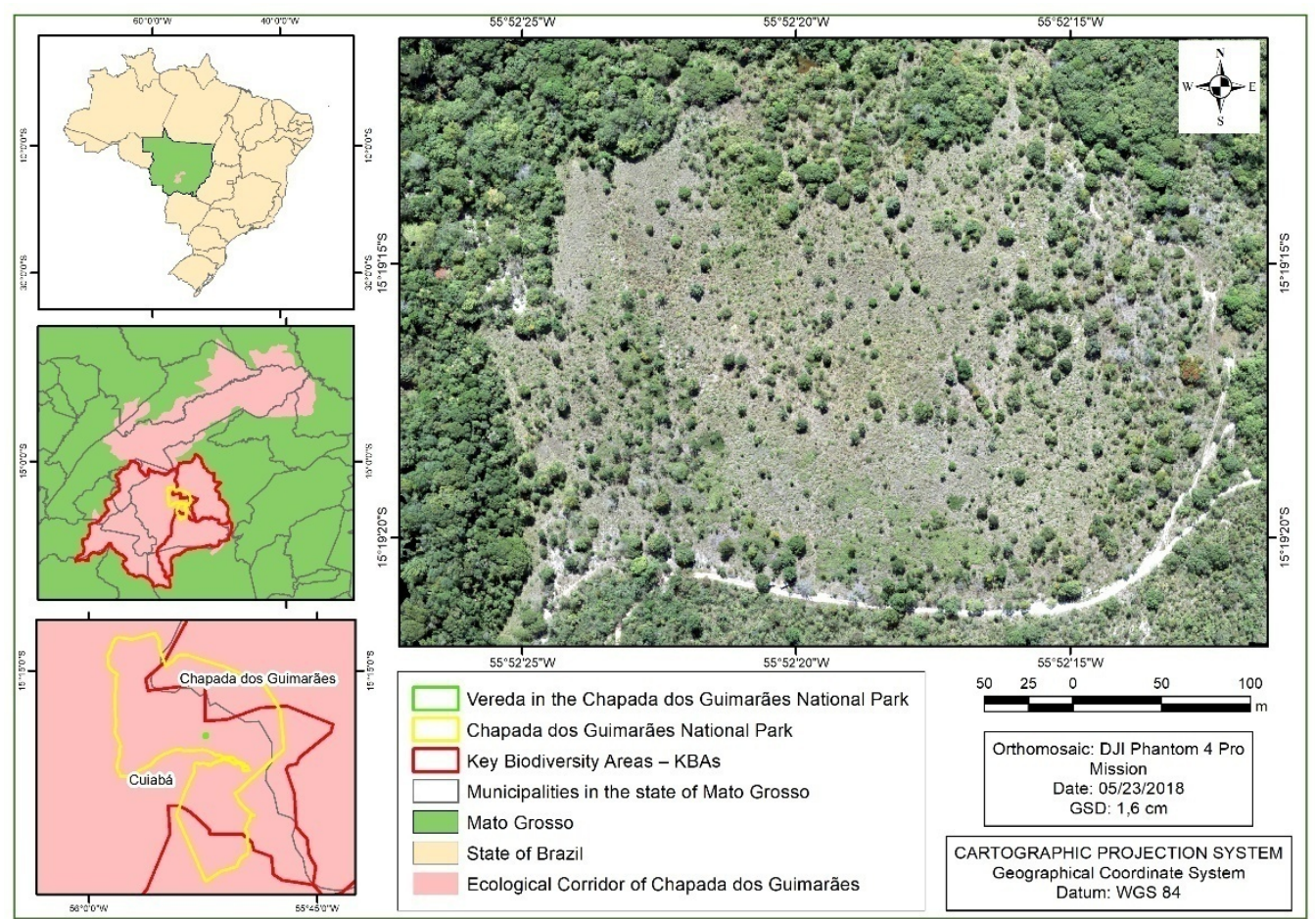

Figure 1. Location of the study area.

The sampled area was subjected to prescribed burning on 23 May 2018 (at 14:30 hours), after 15 years without the influence of fire, under the meteorological conditions of $60 \%$ relative humidity $(\mathrm{RH})$, temperature of $31^{\circ} \mathrm{C}$, and winds in the NE direction with a speed of less than $5 \mathrm{~km} / \mathrm{h}$, according to the Integrated Fire Management (IFM) contained in the park's management plan [24].

The neighboring municipalities of Chapada dos Guimarães and Cuiabá, respectively, comprise the rock formations of the plateau of Chapada dos Guimarães and the Cuiabana Depression, with the latter being defined by the Cuiabá River floodplain, which plays an important role in the formation of Quartzarenic Neosols. The veredas are generally associated with the formation of these soils [25-27].

The climate of the region, according to the Köppen classification, is defined as AW (tropical savanna), with rainy summers and dry winters [28]. The average annual temperature ranges between $22{ }^{\circ} \mathrm{C}$ and $26^{\circ} \mathrm{C}$ [29].

The PNCG occupies an area of 32,630.70 ha, featuring the three physiognomies of the Cerrado biome (forest, savanna, and campestre) [30]. According to [31], the forest formations are divided into the riparian forest, gallery forest, dry forest, and Cerradão, 
being characterized by the predominance of arboreal species with different degrees of deciduousness and association with watercourses.

The campestre formations encompass the campo limpo and campo sujo rupestrian fields, which are recognized by presenting a gradient of more-dense vegetal cover consisting exclusively of herbaceous-shrubby vegetation up to the complete absence of trees [31].

The savanna formations are divided into, namely, Cerrado strictu sensu, Parque de Cerrado, Palmeiral, and Vereda. The first one presents arboreal and shrubby-herbaceous strata in different densities that characterize their subtypes (dense, typical, shallow, and rupestrian). The Parque de Cerrado occurs in small groups at high altitudes in the terrain. Finally, the Palmeiral and Vereda are located in interfluvial regions and feature a single species of palm tree, usually the buriti (Mauritia flexuosa), occurring in lower densities in the veredas compared to the Palmeiral [31].

\subsection{Database}

The study area was surveyed in the following six stages: biomass collection; quality analysis of the land cover; phytosociological survey; collection of control points using a GNSS receiver (type L1/L2, model Hiper Lite+); capture of aerial images (overflights) with a 20-megapixel RGB camera coupled to a DJI Phantom 4 Pro (RPA) and digital processing of data (Figure 2).

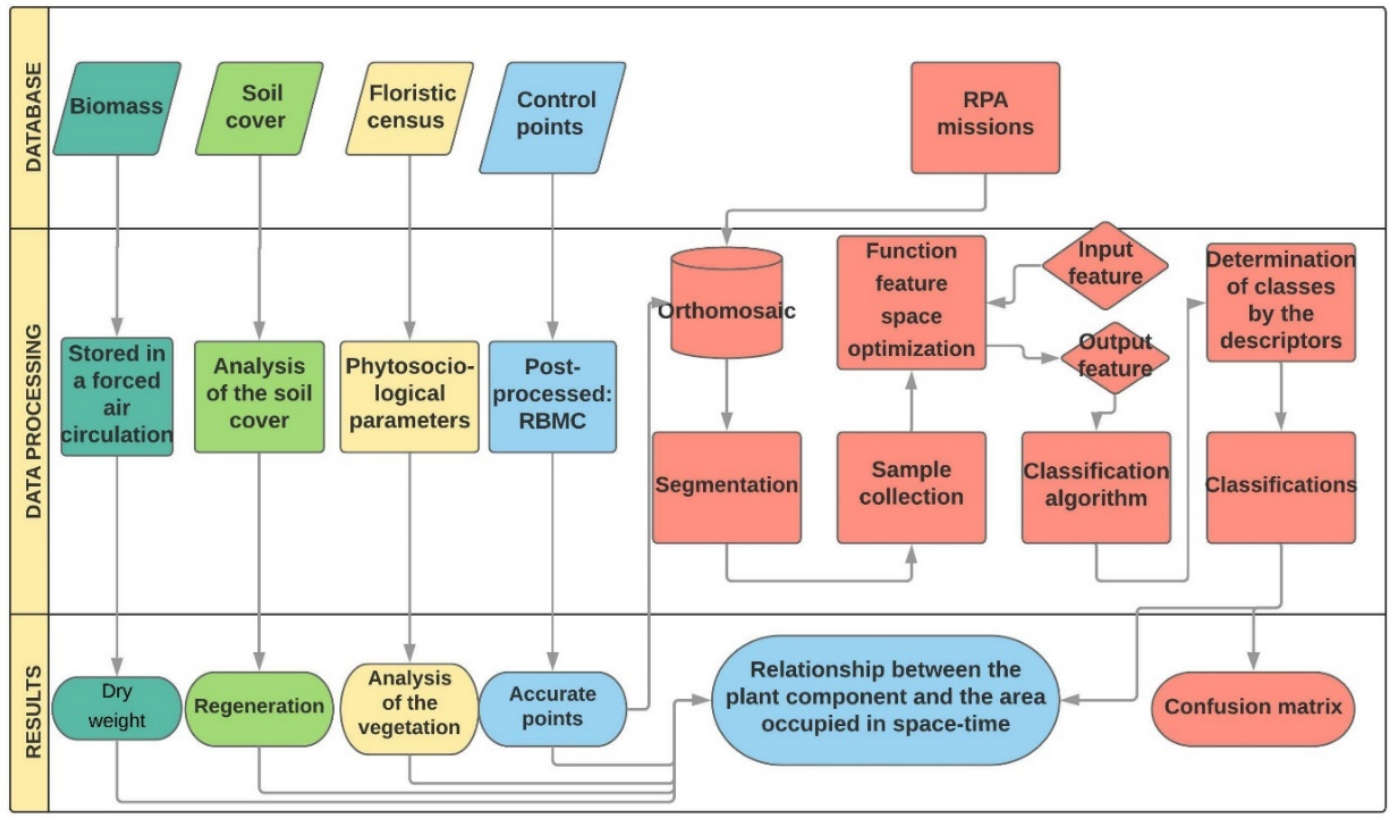

Figure 2. Flowchart of procedures performed in the study area.

\subsubsection{Vegetable Aspects}

Biomass samples were collected in 21 May 2018, before the prescribed burning in the vereda, being randomly distributed in locations with the presence of the pteridophyte identified as Dicranopteris flexuosa. A standard $40 \times 40 \mathrm{~cm}$ template was used for the two samples, in which all biomass at ground level and plant material was collected and stored in a paper bag for proper transport and laboratory weighing. On 19 December 2019, a field visit was carried out at the same locations for a new biomass collection. However, the location still did not present a regrowth of pteridophytes.

The quality analysis of the soil cover was carried out on 7 August 2019, one year after the prescribed burning, when eight sampling points were randomly distributed in the field using a standard $1 \mathrm{~m} \times 1 \mathrm{~m}$ template subdivided into four quadrants.

The phytosociological survey carried out on 19 December 2019 included the floristic census of adult individuals in the central area of the vereda, where the prescribed burning 
occurred. The sampling criteria followed the approaches by [32] with some adaptations, as the collection site was a transition area between grassland vegetation and forest formation.

\subsubsection{Aerophotogrammetry}

Control points are artificial landmarks installed in the field that can be identified in the images and referenced by positioning methods [33], being installed to improve the accuracy of positioning [34].

Thus, the points were collected using rapid static positioning with a permanence of 15 min and latency of one second. Landmarks with white targets were set in the collection sites to obtain the data of the three distinct dates of overflight in the vereda, forming a visible vertex in the captured images.

The aerial images were acquired by RPA using the Litchi application, in which the flight plans, consisting of three to four missions for the total coverage of the study area, were made. The flight missions were carried out on 23 May 2018, 8 June 2018, and 2 July 2019 between 10:00 $\mathrm{h}$ and 13:30 $\mathrm{h}$ to obtain minimum shading. The following features were adjusted in the missions: $70 \mathrm{~m}$ altitude, $75 \%$ longitudinal and $85 \%$ lateral overlap, speed of $10 \mathrm{~m} / \mathrm{s}$, and camera directed at nadir position (i.e., angle of $90^{\circ}$ ).

\subsection{Data Prossessing}

\subsubsection{Vegetation Aspects}

After recording their fresh weight, biomass samples were stored in a forced air circulation oven at $70{ }^{\circ} \mathrm{C}$ until reaching constant dry weight [35].

The quality analysis of the soil cover was evaluated visually and as a percentage according to the area of each quadrant occupied by dead or photosynthetically active biomass, thus indicating the component responsible for this cover and observing the exposure of the soil surface, similarly to the procedure by [36].

The study area was entirely subdivided into $20 \times 50 \mathrm{~m}$ plots in order to perform a floristic census, and individuals of interest were admitted when meeting the inclusion criteria, that is, obtaining $\mathrm{DBH} \geq 15.7 \mathrm{~cm}(\mathrm{DBH}=$ diameter at breast height, with diameter being collected at $1.30 \mathrm{~m}$ above ground level). In this census, individuals of the buriti palm, Mauritia flexuosa L.f., were not considered for the measurements, although their presence in the field was observed.

The diameter was measured using a measuring tape, and the total height was estimated in meters, taking into consideration the highest branch or foliage. Individuals included in the survey were identified according to plant taxonomy by an identification specialist and through consultations to the Brazilian Flora to check the names of the authors.

From the data collected in the census, it was possible to obtain the [37] diversity index $\left(\mathrm{H}^{\prime}\right)$ and the Pielou uniformity index $\left(\mathrm{J}^{\prime}\right)$, according to [38], to indicate the distribution of individuals among species; phytosociological parameters (relative density; frequency; dominance; and Index Of Area Coverage-IOAC), according to [39]; and the clustering index $(\mathrm{CI})$ by [40] to determine the spatial distribution of the species, which was calculated using the Excel software.

\subsubsection{Aerophotogrammetry}

The control points acquired were post-processed using the reference stations of the Brazilian Network for Continuous Monitoring (RBMC, acronym in Portuguese) in the Topcon Tools software. The coordinates of the RBMC stations refer to the Geocentric Reference System for the Americas (SIRGAS) with an accuracy of $\pm 5 \mathrm{~mm}$, provided by the Brazilian Institute of Geography and Statistics-IBGE [41].

During flight planning, photographs of the study area were taken before and after prescribed burning. Separately, the images of each mission were processed along with the control points in the Agisoft Photoscan software, thus generating three orthomosaics of the study area, designated as 'pre-burn', 'post-burn', and 'monitoring', corresponding to the acquisition dates of 23 May 2018, 8 June 2018, and 2 July 2019, respectively, as well 
as generating other byproducts, such as the dense point cloud and the Digital Elevation Model (DEM).

The processes of orthomosaic production in the software were sequentially subdivided into the following five steps: 1 -introduction of orthophotos into the software and indication of control points and their alignment according to geolocation; 2-construction of the dense point cloud; 3-construction of the mesh model through aerotriangulation; 4-construction of the Digital Elevation Model; 5-obtaining the RGB orthomosaic.

The indication of control points in the initial stage of image processing builds the relationship between the image coordinate system and the terrain-following coordinate system, in which the GPS navigation system embedded in the RPA is replaced by the coordinates collected by the Global Navigation Satellite System (GNSS) through the aerotriangulation performed by the processing software, thus using this reference for the entire area and performing so-called georeferencing.

In sequence, the orthomosaics obtained were segmented in the Ecognition software using the algorithm Multi-resolution Segmentation on a scale of 100, taking into consideration the relevance of the shape of 0.3 and compactness of 0.8 as weighing for the degree of influence on segmentation. This implies in an image interpretation that is not represented in individual pixels, but in significant objects.

The segmentation algorithm merges neighboring pixels to create an object by the scale factor, which defines maximum heterogeneity [42,43], thus starting with each pixel and consequently forming an object or region based on the indicated spectral and spatial information and obtaining significantly "homogeneous" areas, so that they can be compared with each other, finally obtaining an image with all objects that can be compared regarding their attributes (shape and spectral value) [43,44].

After segmentation, Object-Based Image Analysis (OBIA) was performed by the Nearest Neighbor classification algorithm (NN) combined with Feature Space Optimization to determine the land cover classes associated with each segment.

The optimization function mathematically finds the most suitable combination of features for application in the NN classifier [43], as indicated by the input object features, which consisted of ten descriptors applied to the three following classified orthomosaics: the standard deviation and band average of each band of the sensor, totaling six descriptors; the maximum difference in the spectral response; the regular format of the object; density; and the customized feature Modified Photochemical Reflectance Index (MPRI).

The latter is a custom feature created through the use of the MPRI (Modified Photochemical Reflectance Index), while the others are features of the layer value derived from the spectral properties of the image objects. The MPRI was applied by editing an equation in the eCognition software to obtain the vegetation index. This index is based on the normalized difference between the green and red bands in the visible region (for RGB cameras) [45]:

$$
\mathrm{MPRI}=(\mathrm{B} 1-\mathrm{B} 2) /(\mathrm{B} 1+\mathrm{B} 2),
$$

where MPRI: vegetation index; B1: digital number of the green band (center wavelength of $532 \mathrm{~nm}$ ); B2: digital number of the red band (center wavelength of $594 \mathrm{~nm}$ ).

For the application of the MPRI, we used the original DNs (digital numbers) of the respective RGB channels without performing radiometric corrections. Although conventional RGB cameras are influenced by different factors, such as light variations, overflights were carried out in a short period of time (of less than 30 minutes), thus ensuring uniform lighting conditions (flights close to noon), cloudlessness, and similar atmospheric conditions on both dates and avoiding variations, such as differences in brightness for the same targets. As evidenced in the discussions of this study, the generation of the MPRI was an important step to optimize the classification method for the OBIA algorithm, even with the use of a conventional RGB camera.

Thus, the objects created by the segmentation in the orthomosaics were analyzed, and training samples were collected for each class of interest for the thematic classification. The samples were collected in the most homogeneous segments observed, with the sampling 
intensity being relative to the area of occupation of each studied class. After several sampling attempts, the function Feature Space Optimization provided the Nearest Neighbor classification algorithm with the descriptors that presented the best distinction between the classes indicated in the sampling.

Finally, the supervised classification resulted in a thematic classification in which the segments that resulted in an adverse class to the real one were adjusted by the assign class algorithm, followed by the average, area, distance, and position descriptors.

Finally, the classifications were validated by calculating the confusion matrix and generating the Kappa index according to the collections of georeferenced photographs and field sampling. The samples were standardized with a dimension of $3 \times 3$ pixels and 20 replicates for each evaluated class.

\section{Results}

The average dry mass of the $D$. flexuosa fern was $213.81 \mathrm{~g}$ in the samples, totaling approximately 4.81 tons estimated for the total area of occupation before prescribed burning. However, until 19 December 2019, there was no regrowth of this cluster at the collection site for a new biomass measurement.

The soil cover analysis at points 1,2,3,4,7, and 8 obtained soil coverage above 50\%, while points 5 and 6 only reached $25 \%$. The quality of this soil cover was restricted to the two following groups: with predominance of dead biomass (leaves and thin branches) at points 1, 4, 6, and 7; with predominance of grasses, at points 2, 3, 5, and 8 (Figure 3). Small fragments of $D$. flexuosa fern clusters were also observed near points 1 and 2 .

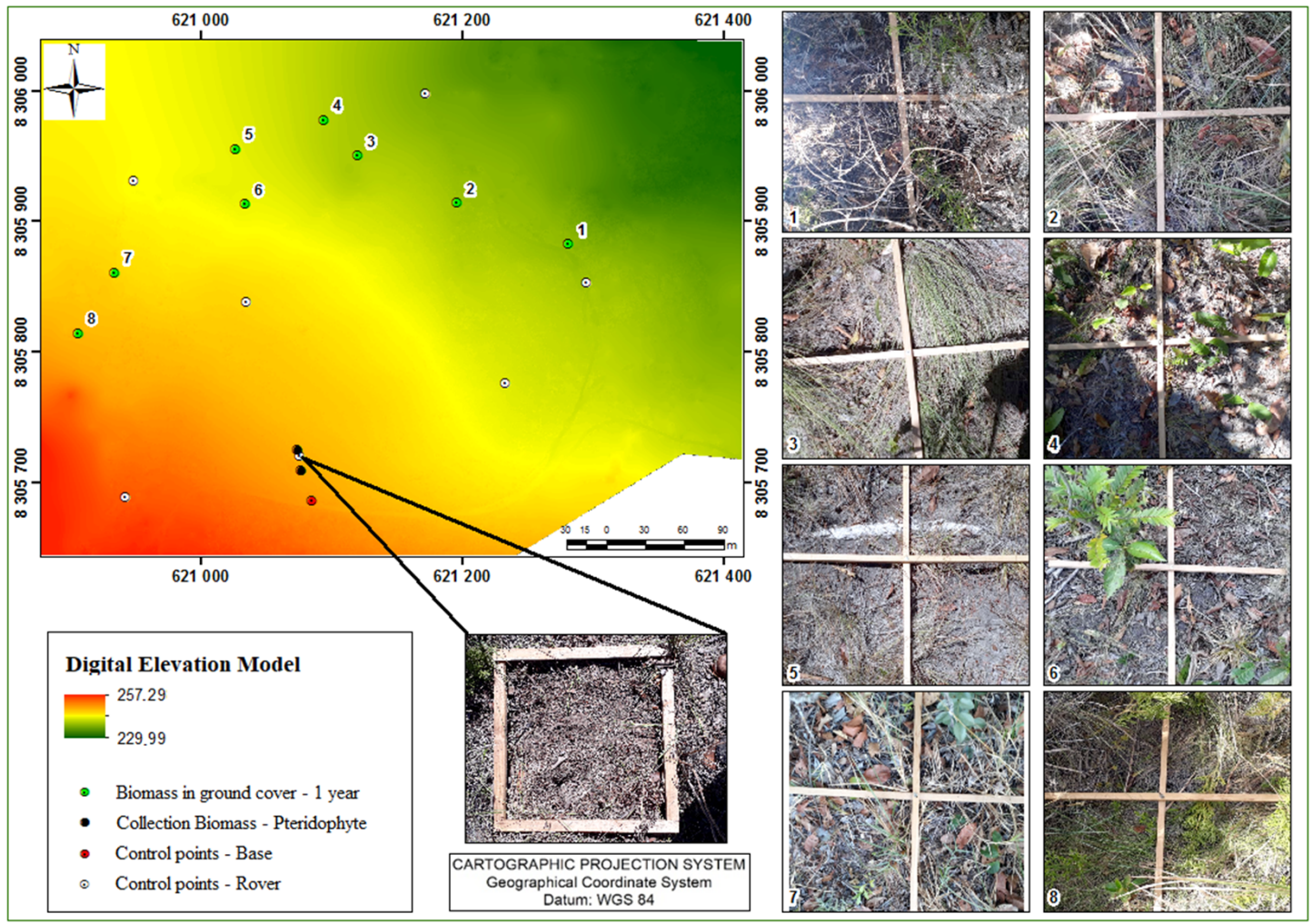

Figure 3. Digital Elevation Model (DEM) with the allocation of control points, biomass collection, and soil cover.

In the phytosociological survey, a total of 713 adult individuals were sampled, comprising a richness of 37 species distributed in 25 families. The Vochysiaceae family stood out for its richness, presenting four species, followed by Malpighiaceae and Lauraceae, with three each. 
Data quantification allowed the observation that $62 \%$ of the area was dominated by Tachigali subvelutina, Byrsonima crassifolia, Tapirira obtusa, and Vochysia haenkeana, where these and four other species (Ferdinandusa elliptica, Ocotea diospyrifolia, Simarouba versicolor, and Hirtella glandulosa) presented a clustering index of $\mathrm{CI}>2$, while the remainder of the individuals in the floristic survey presented a clustering index of $1<\mathrm{CI} \leq 2$.

The diversity $\left(\mathrm{H}^{\prime}\right)$ and evenness $\left(\mathrm{J}^{\prime}\right)$ indices calculated for the vereda after the prescribed burning were 2.60 and 0.40 , respectively.

The generated DEM (Figure 3) allowed the observation that the altimetry of the vereda highlighted the lowest point (in dark green), where the watercourse passage was located, and a higher point (in orange), where the fern cluster was concentrated.

In view of the classification of orthomosaics, different combinations with five descriptors considered as important for differentiating the segments between the soil classes in each orthomosaic were selected by the optimization function (Table 1):

Table 1. Features selected by the optimization function on each classification obtained.

\begin{tabular}{|c|c|c|c|}
\hline & Pre-Burn & Post-Burn & Monitoring \\
\hline \multirow{5}{*}{ Descriptors } & $\begin{array}{c}\text { Standard deviation of } \\
\text { band } 2\end{array}$ & Average of band 1 & Customized MPRI \\
\hline & Maximum difference & Maximum difference & $\begin{array}{c}\text { Average of band } 1 \\
\text { average }\end{array}$ \\
\hline & Average of band 2 & Density & Rectangular shape \\
\hline & $\begin{array}{c}\text { Standard deviation of } \\
\text { band } 1\end{array}$ & $\begin{array}{c}\text { Standard deviation of } \\
\text { band } 2\end{array}$ & $\begin{array}{c}\text { Standard deviation of } \\
\text { band } 1\end{array}$ \\
\hline & Customized MPRI & Average of layer 2 & Maximum difference \\
\hline
\end{tabular}

The verification of the area before prescribed burning resulted in a classification of land occupation distributed in 'fern', defined by the domain of an area of 0.36 ha invaded by the pteridophyte $D$. flexuosa, being located near the roads surrounding the vereda, which were classified as 'exposed soil' ( $0.13 \mathrm{ha}$ ), while the rest of the area was occupied by the 'water blade' in 0.007 ha, the 'arboreal-shrubby' plant strata in 11.47 ha, and the 'herbaceousgrassy' stratum in 8.07 ha (Figure 4).

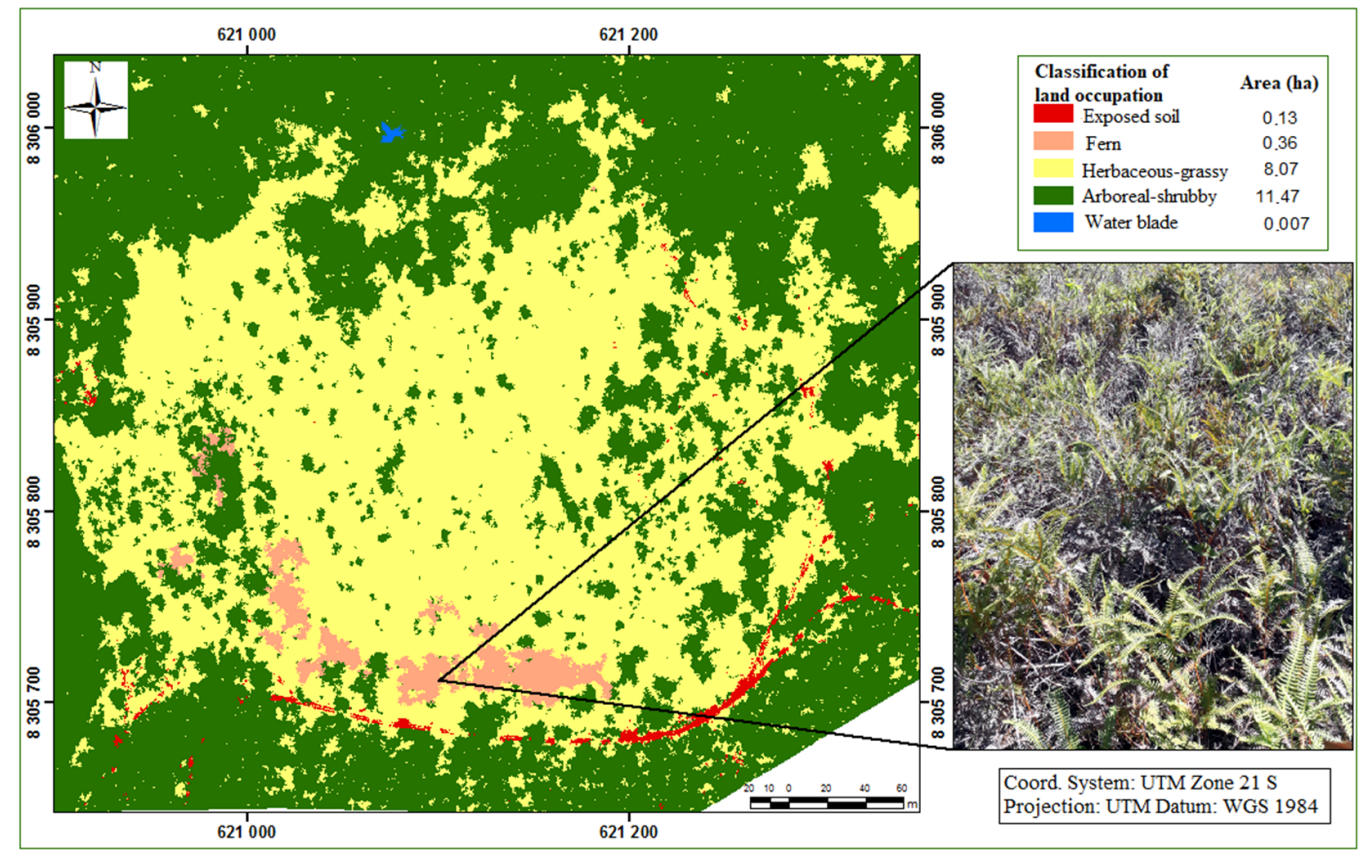

Figure 4. OBIA classification of the orthomosaic image of 23 May 2018-'pre-burn'. 
The 'arboreal-shrubby' classes of plant strata presented the buriti palm that is typical of veredas, Mauritia flexuosa, grouped with other arboreal-shrubby individuals. On the other hand, the 'herbaceous-grassy' class corresponded to grass with the presence of some herbaceous vegetation, especially the Lenten (Tibouchina sp.).

The classification of the 'post-burning' orthomosaic image resulted in nine classes of land use, maintaining the classes of 'water blade', 'arboreal-shrubby', 'herbaceous -grassy', and 'exposed soil', where the latter obtained the same area of the previous classification (0.13 ha); the distributions of other classes were $0.001 \mathrm{ha}, 8.75 \mathrm{ha}$, and 1.90 ha, respectively. The remaining area was occupied by 1.51 ha of 'shade', 1.84 ha of 'remaining shrubs', 0.33 ha of 'white ash', 5.09 ha of 'intermediate ash', and 0.49 ha of 'dark ash', with the latter dominating the site that was previously under the presence of the 'fern' (Figure 5).

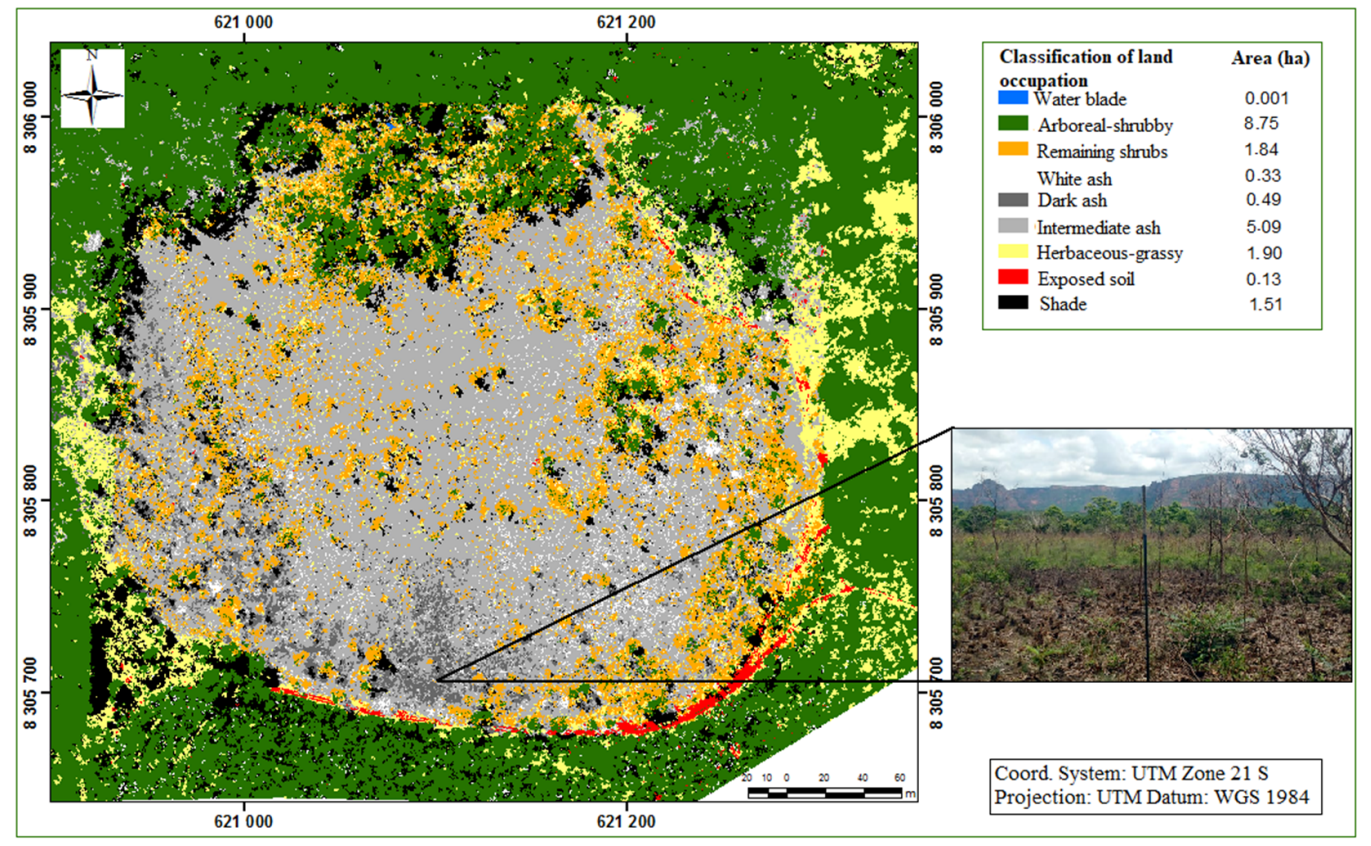

Figure 5. OBIA classification of the orthomosaic image of 8 June 2018-'post-burning'.

After the complete oxidation of organic matter from biological materials, mineral residues (the inorganic portion of the material) form the so-called 'ashes', presenting $\mathrm{K}, \mathrm{Ca}$, and $\mathrm{Mg}$ as the main components [46]. The ash color is a consequence of the progress of the burning flames, the consequent type of combustion (complete or incomplete), the fuel characteristics, and the surface/volume ratio [47].

Finally, the classification of the 'monitoring' orthomosaic image was elaborated without presenting the 'water blade' class due to being recorded in the dry season and due to the consequent decline in the water table. However, the 'shade' (2.73 ha), 'arboreal-shrubby' (7.70 ha), 'herbaceous-grassy' (2.80 ha), and 'exposed soil' ( $0.12 \mathrm{ha})$ classes remained. The rest of the area was occupied in a small area of 0.17 ha by 'fern' in the elevated part of the vereda, and mostly by the 'regenerated' and 'non-regenerated' classes, with 5.34 ha and 1.18 ha, respectively, with the latter observed in the sites initially occupied by the fern before the prescribed burning (Figure 6). 


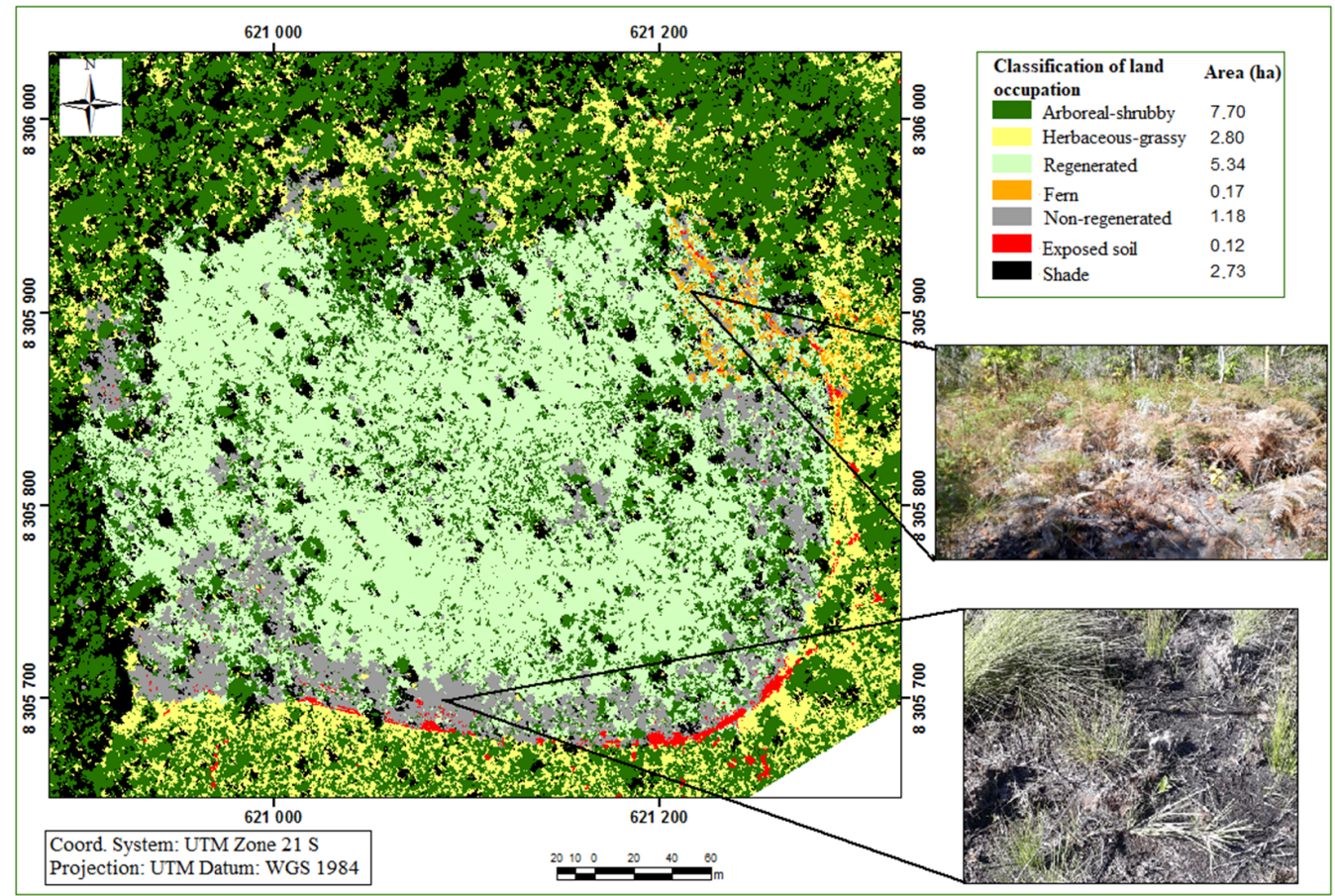

Figure 6. OBIA Classification of the orthomosaic image of 2 July 2019-'Monitoring'.

The orthomosaic classifications of 'pre-burn', 'post-burn', and 'monitoring' obtained accuracy and Kappa indices [48] equal to $94.22 \%$ and $0.93,82.74 \%$ and 0.81 , and $85.87 \%$ and 0.83 , respectively.

\section{Discussion}

The analysis of biomass and dense soil cover, corresponding to the occupation of the fern $D$. flexuosa, indicated the characterization of understory vegetation in the study area. In agreement with its presence, in [49], it was called 'Dicranopteris-dominated understory', which is considered as a colonizer in the initial stage of succession of acidic and oligotrophic soils.

The species richness in the location presented a smaller number of species than that found in 2014 by [50] (143 species), [51] (174 species), and [52] (101 species), as the herbaceous-subshrubby component of regeneration was not collected in this study. This component is well represented by the Poaceae family and is highlighted for presenting a greater number of species, greater frequency, and consequent greater relative coverage in veredas when compared to other families [50-53].

In the floristic survey, the species B. crassifolia, T. obtusa, T. subvelutina, and V. haenkeana accounted for $62 \%$ of the coverage of the area, in which the latter has the function of indicating an ecotone environment among the types of Cerrado vegetation [54]. In addition, $B$. crassifolia is of significant ecological importance in transitional Cerrado vegetations $[55,56]$. Finally, T. subvelutina is characterized by starting secondary succession in open areas and colonizing marginal lands $[57,58]$.

It should be noted that impacted veredas allow colonization with species from the surrounding areas [59], which may favor the natural tendency of T. subvelutina. Changes occur in a constant gradient of species substitution, comprising components from neighboring zones and exclusive species [51].

The species B. crassifolia and T. obtusa and two other species found in smaller numbers, C. brasiliense and X. emarginata, are characteristic of marshy terrain close to rivers and slopes [60-62], where the species X. emarginata may reflect the environmental preservation of the habitat [59]. 
The analysis of the species found in the area showed that their distribution may indicate the zoning within the vereda according to the period of soil moisture, presenting a gradient from darker and water-saturated soils (bottom zone) to clearer soils with good drainage (edge zone) [63].

Thus, the species X. aromatica, C. Americana, and M. albicans are individuals from edge zones; $C$. pachystachya and $M$. flexuosa belong to bottom zones; and the fern with grass habit (D. flexuosa) is established in all areas of the vereda (middle, bottom, and edge) [63].

Regarding the physiognomies of the Cerrado for the establishment of some species, the affinity of the species M. albicans, M. splendens, Q. parviflora, Q. multiflora, H. alchorneoides, C. brasiliense, and C. pachystachya with wetter environments, such as areas of veredas and floodplains, also found in other physiognomies of the Cerrado, is noted [62]. The species $R$. grandis, H. glandulosa, and H. balsamifera are distributed in riparian and gallery forests. Other species, such as B. coccolobifolia, B. crassifolia, A. edulis, and C. americana are located preferably in grassland vegetation and dry cerradões.

In general, the species in the vereda habitat are not arranged permanently. Thus, the performance of a phytosociological survey is recommended more than once a year, preferably at the peak of the wet season and at the beginning of the dry season, in order to cover greater floristic variety [51,64].

In the analysis of ecological parameters, dispersion influences abundance and obtains the following spatial patterns: cluster, random, and regular [65].

Abundance is regulated at a specific level by the processes of competition, predation, and parasitism, noting that the stability of a population does not mean inertia, but a complex dynamic of ideal numbers of individuals [65], as analyzed by [66] in a study in a vereda area, showing that richness and diversity did not vary significantly over time.

The diversity of the area, obtained by the Shannon and Weaver index found in the present study, reached values similar to those found in vereda areas by [50], from 2.4 to 2.9 in middle zones, where the areas were not disturbed, and by [67], in a vereda in the urban area of the Federal District, 2.29, accompanied by the evenness index of 0.72 , describing the environment as being preserved, and reached different values to those found in a Cerrado strictu sensu vegetation, where 3.51 diversity and 0.85 evenness were obtained [66].

Thus, the present study obtained a Shannon and Weaver index value similar to other studies, and it can be said that the vereda under study was in good preservation conditions. The low evenness value evidenced the concentration of species in specific samples according to the defined zones of the landscape proposed by the CI, where the entire population presented a tendency to cluster or were already clustered.

Then, the DEM evidenced a flat relief in the central part for presenting very small unevennesses and soft undulations at the edges of the vereda, with relative altitudes of up to $50 \mathrm{~m}$, which was pertinent to the observations in [68] and also to the characterization of the sites of the establishment of veredas, which are discriminated by depressed portions of the relief of oval or linear shape, or directed within an area that is structurally flat or flattened by erosion [9].

By observing the thematic classification of orthomosaics, it is concluded that the use of the optimization function was satisfactory for the initial determination of the segments in the respective classes of soil cover, as verified by [69] when concluding with certainty that the employment of the aforementioned tool provided the best combination of features, based on training samples, for soil cover.

According to the behavior of vegetation along the visible spectrum (RGB), it is possible to observe that the relationship between the green and red bands is similar to the relationship between the infrared and red bands [45].

The selection of bands 1 (green) and 2 (red) occurred as the spectral range of red presented an absorption peak in the reflectance values of the vegetation due to chlorophyll pigments. Conversely, the spectral range of green tends to increase the intensity of reflection [70]. 
The 'exposed soil' class mostly expressed the access routes to the macrohabitat; the 'water blade' class exposed the water table outcrop, conditioning the vereda environment described by [31], and the plant strata 'arboreal-shrubby' and 'herbaceous-grassy' comprised the vegetation complex that typifies the vereda macrohabitat [71], with a shrub and/or arboreal row characterized by the presence of buriti palms $[9,72]$. The shrubby-herbaceous stratum is generally surrounded by a clear humid field, consisting predominantly of herbaceous vegetation with rare shrubs and the complete absence of trees [31].

However, in [73], it was emphasized that veredas can present different configurations according to their stage of development. Stage 1 is characterized by the surroundings of the water source being occupied by dense herbaceous vegetation with a predominance of young grasses and buriti palms. The second stage presents the addition of shrubs, subshrubs, and seedless vascular plants. The appearance of climbing plants and tree species installed along the drainage channel characterizes the third stage of development, ending the fourth stage with a deeper drainage channel and the presence of a gallery forest.

It is noted that the center of the vereda is no longer characterized as a campo limpo due to the large presence of arboreal-shrubby individuals, evading the conventional classification by [31]. Thus, it can be inferred that the area is probably undergoing a process of ecological succession to a new stage of development of the vereda, also taking into consideration the disposition and characteristics of the species present in the environment.

Succession encompasses changes in the structure of community composition by the development of initial vegetation up to the climax or by gradual substitution by another community, increasing biological complexity [74], as already observed by the natural tendency of T. subvelutina to colonize open and marginal areas.

This evolutionary relationship of the savanna is also related to the frequency of fire. In this study, this relationship was represented by the species K. coriacea and C. pachystachya, which regenerated quickly and efficiently, being also of great importance for the reestablishment of the fauna $[75,76]$. However, excess fire becomes harmful $[77,78]$.

Fire induces flowering in individuals of some savanna species by destroying their epigeal parts and not by a thermal or nutritional effect (ashes) or by the elimination of apical dominance [79].

The interaction of fire in a vereda area is more difficult to be controlled or extinguished during drought due to the thickness of the layer of organic soil that is characteristic of this type of environment, providing excellent combustible material [20]. Thus, since many ecosystems depend on it to preserve native species, fire has become a conservation issue [80].

Therefore, the environmental conditions obtained ( $\mathrm{RH}: 60 \%, \mathrm{~T}: 31^{\circ} \mathrm{C}$, and winds in the $\mathrm{NE}$ direction $<5 \mathrm{~km} / \mathrm{h}$ ) were crucial for a mild prescribed burning without irreversible damage to the vegetation.

The classification obtained by the 'post-burning' orthomosaic enabled the verification of the intensity of fire occurrence in the study area. Generally, materials with a large amount of silica, such as grasses, accelerate the effects of fire when compared to other types of fuels [81].

The white ash tends to be in front of the fire due to the desiccation of fuel by radiation and convection prior to the arrival of the flames. It also shows fire ignition sites, contrasting with the darker ash surrounding it, thus consisting of the complete burning of fuel (preheating, gas combustion, and combustion of woody material) [47].

On the other hand, dark ash, regardless of location in the fire area, is characteristic of incomplete burning due to moisture and the vegetative vigor of fuels, lacking greater thermal energy for radiation and convection for complete burning [47].

Incomplete burning is a characteristic of high-speed and high-intensity fires [79], and this type of combustion was observed in locations previously occupied by D. flexuosa. The fern infestation provides a 1-3 m-tall layer of dense biomass that is highly flammable in the dry season, when the occurrence, duration, and intensity of fires increase [82]. Thus, it is 
noted that the most severe fire was limited to the perimeter of distribution occupied by this pteridophyte.

Fire maintains an important relationship in the increase in species diversity and in the renewal of the vegetation of the Cerrado biome, in structural and physiological characteristics $[50,83,84]$, as well as in activities that disturb the environment due to the environmental heterogeneity produced in the uniform structure of the environment [52].

High-frequency fire reduces the diversity of tree species without the same effect on the herbaceous-subshrub structure [85], as high mortality rates in campo sujo and cerrado strictu sensu were observed after prescribed fires [81].

In the studies by [86,87], the pyrophilic nature of Mauritia flexuosa (buriti palm) provided a relationship between increasing fire and the appearance of this species. However, the incidence of fire within an interval of less than ten years reduces the size of buriti palm populations, as they are unable to recover [11].

Some studies in Venezuela have shown that grasses grow better after a fire, as the accumulated biomass of the herbaceous-subshrub stratum on the ground decreases [64], which was observed in the 'monitoring' classification.

In view of the consequences, advantages, and needs of vereda vegetation, it is emphasized that not every fire in veredas is devastating and harmful, taking into consideration that there is a need and opportunity to subsidize and define management rules to guide the appropriate fire regime for different phytophysiognomies, as in the vereda, and to define the productive uses of the Cerrado with a view to establishing the compatible use of fire and conservation in these areas [11]. Therefore, it is necessary to determine factors such as frequency, behavior, severity, burning time, and extent of burned areas to define the so-called 'fire regime' [47].

The sites that were still not regenerated concentrated in areas formerly occupied by $D$. flexuosa were easily elucidated, as D. flexuosa has the ability to colonize the environments and prevent the establishment of other plants, which is a behavior similar to that presented by Pteridium aquilinum, although few studies have evaluated the allelopathic potential of pteridophyte species [88].

The fern $D$. flexuosa typically occurs when being surrounded by forest areas in medium and advanced stages of regeneration, whereas in the herbaceous stratum, the dominance of the fern is an indicator of an area of recent regeneration. Thus, D. flexuosa is a species typical of highly altered areas due to the fixation of this and other rustic species [89] exclusive to anthropized environments of the vereda, being favored in this context [52].

The strata consisting of pteridophytes, despite being present in some veredas, are not a flora that is characteristic of this environment. Therefore, the nature of this ecosystem is exclusive, and the association of the fern is more related to the water regime [90].

Pteridium settles in well-structured and deep soils [88], as well as being preferred in locations with the presence of sunlight during most of the day [91].

In areas of anthropized and preserved veredas that have access to flows of cattle, the invasion of several pteridophytes occurs naturally. However, the fern variety is more favored when in the second situation [90] due to favorable environmental conditions and the great potential for the dispersal of propagules.

In general, invasive exotic species are among the main direct causes of biodiversity loss and species extinction, along with climate change and habitat loss due to exploitation and pollution, according to Resolution No. 7/2018 [92]. Thus, the Convention on Biological Diversity promulgated by Decree No. 2519/1998 [93] established that according to the individuality of each case, the introduction of exotic species that threaten ecosystems, habitats or species must be prevented through their control or eradication.

Thus, the construction of prevention plans and early detection of invasive exotic species directs efforts towards identifying its vectors and dispersing these species, as the most common species have greater chances of invading conservation units even if they did not present invasive behavior in a specific area but presented a history of invasion in another region [94]. 
Obtaining the accuracy and Kappa index of the classifications of the 'pre-burn', 'postburn', and 'monitoring' orthomosaic images reached an 'excellent' concept regarding the correspondence between the analyzed elements.

Similarly, in [95], photogrammetry was applied in an integrated way with field data, evaluated before and after the burn and detailed with pre-burn photogrammetric data, through RPA products equipped with a multispectral sensor. The multispectral bands were used to calculate vegetation index to estimate fire severity, obtaining between 7.22 and $3 \mathrm{~cm}$ of GSD, and a Kappa index of approximately 0.582. On the other hand, in [96], was used an RPA equipped with RGB with spatial resolution of 6 and $10 \mathrm{~cm}$ was used to determine the severity of the fire, which obtained a Kappa index of approximately 0.37.

Thus, with the use of RPA for monitoring the IFM in relation to pre-burning, studies are being conducted through the use of aerial image capture, not in-person observations. One can measure the application of RPA as the study of fire severity is the specific resolution of the application in the sensor, while a delimitation process of the spatial determination and determination of plant distribution is influenced by the resolution.

\section{Conclusions}

The use of RPAS allowed the diagnosis of native and invasive vegetations regarding their responses to prescribed burning, which indicated that fire acted as a renewer of vegetation, being enough to inhibit the growth of the invasive fern in the same location for up to one year and providing an opportunity for the establishment of other species after one year, such as grass individuals, although in small numbers.

The invasive pteridophyte D. flexuosa occupied the largest land area in May 2018 (end of the rainy season), while occupying the smallest land area towards the interfluve in June 2019 (dry season). Thus, it is stated that the fern cluster is related to soil moisture, but is not related to complete saturation as it occupied the area close to the interfluve at a time when the water table level was low. It was possible to establish an occupation zone of this understory vegetation according to the soil moisture and associated with the presence of anthropization, as it was established near roads.

Regarding the 'arboreal-shrubby' and 'herbaceous-grassy' strata analyzed by RPAS, it was possible to identify the introduction of arboreal individuals in the campo limpo habitat, and it can be inferred that the vereda was in the process of ecological succession.

The phytosociological study after prescribed burning provided the basis for evaluating the diversity of adult individuals established in the area and eliminated the possibility of the tree/shrub invasion of neighboring areas.

The diversity found in this study competes with that of other studies, as the zoning of habitats within the veredas select the species that would inhabit every location.

The vereda is undergoing a process of maturation and not invasion, as among inventoried species, some are characteristic of primary environments, and the majority is characteristic of secondary environments. The four species responsible for $62 \%$ of the vegetation cover were individuals from secondary forests, with the purpose of shading the area to prepare the environment for individuals of the climax forest.

The environment, presented a dynamic of substitution and occupation of the available space, where the population would reach its peak and would soon start to show a decline in some individuals due to the regulatory activities of abundance (competition, predation and parasitism), thus reaching the normality of the population of individuals.

The study highlighted the effectiveness of Integrated Fire Management, which enables the diagnosis of changes in the landscape of the wetland of the vereda, mainly due to the use of very high spatial resolution data obtained by RPAS combined with advanced techniques with the use of OBIA.

Finally, the present study confirmed the applicability of RPAS coupled to an RGB camera together with field work in the identification of species, which is sufficient to monitor and analyze the dynamics of vegetation in relatively small areas by detecting 
anomalies in the environment, such as the proliferation of invasive individuals and the distribution and zoning of the microhabitat.

Author Contributions: Conceptualization: J.C.N. and G.M.N.; methodology: J.C.N. and G.M.N.; software: J.C.N. and G.M.N.; validation: J.C.N. and G.M.N.; formal analysis: J.C.N., G.M.N. and M.E.F.; investigation: J.C.N., G.M.N. and M.E.F.; resources: G.M.N.; data curation: J.C.N., G.M.N. and M.E.F.; writing—original draft preparation: J.C.N., G.M.N. and M.E.F.; writing—review and editing: J.C.N., G.M.N. and M.E.F.; visualization: J.C.N., G.M.N. and M.E.F.; supervision: G.M.N. and M.E.F.; project administration: G.M.N.; funding acquisition: G.M.N. All authors have read and agreed to the published version of the manuscript.

Funding: This research was funded by the Critical Ecosystem Partnership Fund (CEPF)—Cerrado Hotspot, CEPF/02/2017-P52/7201-003 and CEPF \#103768. The first author received a scholarship from the Coordination for the Improvement of Higher Education Personnel (CAPES, Brazil)_Finance Code 001. The postgraduate program in Environmental Sciences (CIAMB) at the Federal University of Goiás (CAPES AUXPE \#0887/2018) and WWF Brasil have supported this publication. M.E.F. is a CNPq Research Fellow (grant \#315699/2020-5).

Data Availability Statement: Not applicable.

Acknowledgments: The authors are grateful to LabSensoR and the entire team for their assistance in digital processing and fieldwork. They also thank the Gustavo Nunes and Manuel Ferreira for his guidance throughout the study. We are grateful to the Chico Mendes Institute for Biodiversity Conservation (ICMBio) from the Chapada dos Guimarães National Park (PNCG) and, in particular, to Luiz Gustavo Gonçalves, for their support in field activities and to all PPGCFA and undergraduate coordination staff for their dedication to this paper. Finally, without CEPF's support in the defense of Key Biodiversity Areas, this research would not be possible.

Conflicts of Interest: The authors declare no conflict of interest.

\section{References}

1. Leão, T.C.C.; Almeida, W.R.; Dechoum, M.; Ziller, S.R. Espécies Exóticas Invasoras no Nordeste do Brasil: Contextualização, Manejo e Políticas Públicas; Centro de Pesquisas Ambientais do Nordeste e Instituto Hórus de Desenvolvimento e Conservação Ambiental: Recife, Brazil, 2011; Volume 1,99p.

2. $\quad$ Richardson, D.; Pysek, P.; Rejmanek, M.; Barbour, M.G.; Panetta, F.D.; West, C.J. Naturalization and invasion of alien plants: Concepts and definitions. Divers. Distrib. 2000, 6, 93-107. [CrossRef]

3. Archer, S.R.; Andersen, E.M.; Predick, K.I.; Schwinning, S.; Steidl, R.J.; Woods, S.R. Woody Plant Encroachment: Causes and Consequences. In Rangeland Systems: Processes, Management and Challenges; Briske, D.D., Ed.; Springer International Publishing: Cham, Switzerland, 2017; pp. 25-84. [CrossRef]

4. Lehmann, D.R.M. Estudos sobre a propagação de Gleichenella pectinata (Willd.) ching (pteridófita-Gleicheniaceae). In Dissertação (Mestrado em Biologia Vegetal); Universidade Federal de Santa Catarina: Florianópolis, Brazil, 2008; 54p.

5. Arantes, A.A.; Prado, J.; Ranal, M.A. Monilófitas da Estação Ecológica do Panga, Uberlândia, Estado de Minas Gerais, Brasil: Dennstaedtiaceae, Dryopteridaceae, Gleicheniaceae, Hymenophyllaceae e Lindsaeaceae. Hoehnea 2008, 35, 367-378. [CrossRef]

6. Melo, L.C.; Salino, A. Pteridófitas de duas áreas de floresta da bacia do Rio Doce no estado de Minas Gerais, Brasil. Lundiana Int J. Biodivers. 2002, 3, 129-139. [CrossRef]

7. Lima, L.V.; Salino, A. Gleicheniaceae in Flora do Brasil 2019 em Construção. Jardim Botânico do Rio de Janeiro. Available online: http:/ / floradobrasil.jbrj.gov.br/reflora/floradobrasil/FB91164 (accessed on 18 February 2020).

8. Windisch, P.G. Pteridófitas do Estado de Mato Grosso: Gleicheniaceae. BRADEA-Bol. Do Herb. Bradeanum 1994, 6, $304-311$.

9. Carvalho, A.C.A. Análise ambiental de um subsistema de vereda em unidade de conservação: Reserva Ecológica do IBGE- RECOR e Estação Ecológica de Águas emendadas ESECAE/DF Brasília/DF. Master's Thesis, Universidade de Brasília, Distrito Federal, Brasilia, Brazil, 2015; 127p. [CrossRef]

10. BRASIL. Lei n 12.651, De 25 De Maio De 2012. Available online: http://www.planalto.gov.br/ccivil_03/_ato2011-2014/2012/ lei/112651.htm (accessed on 15 February 2022).

11. Borges, S.L.; Eloy, L.; Schmidt, I.B.; Barradas, A.C.S.; Dos Santos, I.A. Fire Management in Veredas (Palm Swamps): New Perspectives on Traditional Farming Systems in Jalapão, Brazil. Ambient. Soc. 2016, 19, 269-294. [CrossRef]

12. Miguel, E.P.; Rezende, A.V.; Leal, F.A.; Matricardi, E.A.T.; Vale, A.T.D.; Pereira, R.S. Redes neurais artificiais para a modelagem do volume de madeira e biomassa do cerradão com dados de satélite. Pesqui. Agropecuária Bras. 2015, 50, 829-839. [CrossRef]

13. Alba, E.; Mello, E.P.; Marchesan, J.; Silva, E.A.; Tramontina, J.; Pereira, R.S. Spectral characterization of forest plantations with Landsat 8/OLI images for forest planning and management. Pesqui. Agropecuária Bras. 2017, 52, 1072-1079. [CrossRef] 
14. De Almeida, A.Q.; De Mello, A.A.; Neto, A.L.D.; Ferraz, R.C. Relações empíricas entre características dendrométricas da Caatinga brasileira e dados TM Landsat 5. Pesqui. Agropecuária Bras. 2014, 49, 306-315. [CrossRef]

15. Furtado, L.F.D.A.; Silva, T.S.F.; Fernandes, P.J.F.; Novo, E.M.L.D.M. Land cover classification of Lago Grande de Curuai floodplain (Amazon, Brazil) using multi-sensor and image fusion techniques. Acta Amaz. 2015, 45, 195-202. [CrossRef]

16. Kurtz, B.C.; Magalhães, A.M.; Seabra, V.D.S.; Richter, M.; Caris, E.A.P. Integrating remote sensing and phytosociology of the Atlantic Forest to map a small continental island in southeastern Brazil: Subsidies to protect the habitat of critically endangered species. Rodriguésia 2018, 69, 2081-2092. [CrossRef]

17. Alvarado, S.T.; Fornazari, T.; Costola, A.; Morellato, P.; Silva, T. Drivers of fire occurrence in a mountainous Brazilian cerrado savanna: Tracking long-term fire regimes using remote sensing. Ecol. Indic. 2017, 78, 270-281. [CrossRef]

18. de Almeida Furtado, L.F.; Francisco, C.N.; de Almeida, C.M. Análise de imagem baseada em objeto para classificação das fisionomias da vegetação em imagens de alta resolução espacial. Geociências 2013, 32, 3, 441-451.

19. Souza, J.M.F.; dos Reis, E.F.; Martins, A.S.; Santos, A.L.F. Avaliação dos conflitos no uso da terra na bacia hidrográfica do ribeirão Lamarão, Distrito Federal. Ciência Florest. 2019, 29, 950-964. [CrossRef]

20. Maillard, P.; Pereira, D.B.; Souza, C.G. Incêndios florestais em veredas: Conceitos e estudo de caso no Peruaçu. Rev. Bras. Cartogr. 2009, 61, 321-330.

21. Fontes, J.C.; Pozzetti, V.C. O uso dos veículos não tripulados no monitoramento ambiental na Amazônia. Rev. Direito Sustentabilidade 2016, 2, 149-164. [CrossRef]

22. Longhitano, G.A. VANTs Para Sensoriamento Remoto: Aplicabilidade na Avaliação e Monitoramento de Impactos Ambientais Causados por Acidentes de Carga. Master's Thesis, Escola Politécnica da Universidade de São Paulo, São Paulo, Brazil, 2010 163p.

23. MMA; ICMBIO; PNCG. Plano de Manejo Parque Nacional da Chapada dos Guimarães; Chapada dos Guimarães, Mato Grosso, Brazil, 2009. Available online: https://www.icmbio.gov.br/portal/images/stories/imgs-unidades-coservacao/parna_chapada-dosguimaraes.pdf (accessed on 1 February 2022).

24. ICMBio. Plano de Prevenção e Combate a Incêndios Florestais e Manejo Integrado e Adaptativo do Fogo do Parque Nacional da Chapada dos Guimarães. 2016. Available online: http://reflorestamentoecarbono.com.br/wp-content/uploads/2016/04/planode-protecao-pncg.pdf (accessed on 18 February 2020).

25. Silva, R.; Paixão, E.; Cunha, C.; Finger, Z. Fitossociologia da comunidade arbórea de cerrado sensu stricto do Parque Nacional da Chapada dos Guimarães. Nativa 2016, 4, 82-86. [CrossRef]

26. Spera, S.T.; Reatto, A.; Martins, E.D.S.; Correia, J.R.; Cunha, T.J.F. Solos areno-quartzosos no cerrado: Características, problemas e limitações ao solo. Planaltina Embrapa Cerrados 1999, 7, 48.

27. Neves, W.V.; Menezes, E.P.; de Oliveira, F.S.; Augustin, C.H.R.R.; Aranha, P.R.A. Estudos das coberturas superficiais na interface cerrado-vereda no norte de Minas Gerais. Rev. Bras. Geomorf. 2015, 16, 351-367. [CrossRef]

28. Alvares, C.A.; Stape, J.L.; Sentelhas, P.C.; de Moraes Gonçalves, J.L.; Sparovek, G. Köppen's climate classification map for Brazil. Meteorol. Z. 2013, 22, 711-728. [CrossRef]

29. ANA-Agência Nacional de Águas; GEF; PNUMA; OEA. Implementação de Práticas de Gerenciamento Integrado de Bacia Hidrográfica para o Pantanal e Bacia do Alto Paraguai ANA/GEF/PNUMA/OEA: Programa de Ações Estratégicas para o Gerenciamento Integrado do Pantanal e Bacia do Alto Paraguai: Relatório Final 2004; Campo Grande, Mato Grosso do Sul, Brazil, 2005; 137p. Available online: https:/ / www.ecoa.org.br/wp-content/uploads/2015/11/RE_51MS.pdf (accessed on 1 February 2022).

30. ICMBio-Instituto Chico Mendes de Conservação da Biodiversidade. Plano de Manejo: Parque Nacional da Chapada dos Guimarães. 2009. Available online: http://www.icmbio.gov.br/parnaguimaraes/images/stories/downloads/capa_ apresentacao_e_indice.pdf (accessed on 7 October 2019).

31. Ribeiro, J.F.; Walter, B.M.T. As principais fitofisionomias do Bioma Cerrado. In Cerrado: Ecologia e Flora; Sano, S.M., Almeida, S.P., Ribeiro, J.F., Eds.; Embrapa Cerrados: Brasília, Brazil, 2008; pp. 151-212.

32. Felfili, J.M.; Carvalho, F.A.; Haidar, R.F. Manual Para o Monitoramento de Parcelas Permanentes nos Biomas Cerrado e Pantanal; Universidade de Brasília, Departamento de Engenharia Florestal: Brasília, Brazil, 2005; 55p.

33. dos Santos, L.F.B. Avaliação de Modelo Digital de Terreno Gerado Através de VANT em Planícies Pantaneiras; Monografia (Graduação em Engenharia Florestal). Master's Thesis, Universidade Federal de Mato Grosso-UFMT, Cuiabá, Brazil, 2016; 53p.

34. Prina, B.Z.; Trenti, R. GPS x GNSS: Constelação GLONASS maximizando a precisão e acurácia dos dados. Rev. Eletrônica Gestão Educ. E Tecnol. Ambient. Santa Maria 2015, 19, 344-352.

35. Arevalo, L.A.; Alegre, J.C.; Vilcahuaman, L.J.M. Metodologia para Estimar o Estoque de Carbono em Diferentes Sistemas de uso da Terra; Colombo Embrapa Florestas: Colombo, Brazil, 2002; Volume 73, 41p.

36. Meschede, D. Avaliação de diferentes coberturas na supressão de plantas daninhas no cerrado. Planta Daninha 2007, 25, 465-471 [CrossRef]

37. Shannon, C.E.; Weaver, W. The Mathematical Theory of Communication; University of Illinois Press: Urbana, IL, USA, 1949.

38. Brower, J.E.; Zar, J.H. Field and Laboratory Methods for General ecology; Wm. C. Brown Company: Dubuque, Iowa, $1984 ;$ p. 226.

39. Mueller-Dombois, D.; Ellenberg, H. Aims and Methods of Vegetation Ecology; John Wiley \& Sons: New York, NY, USA, 1974; p. 547.

40. Mcguinnes, W.G. A relação entre índice de frequência e abundância aplicada a populações de plantas em uma região semi-árida. Ecology 1934, 16, 263-282. 
41. Collischonn, C.; de Lima, E.M.; Ruiz, L.F.C.; Araujo, T.D.; Matsuoka, M.T. Posicionamento GNSS: Comparação entre coordenadas oficiais de estações da RBMC e as obtidas por PPP e posicionamento relativo e ajustamento. In Simpósio Brasileiro de Sensoriamento Remoto-SBSR; INPE: João Pessoa, Brazil, 2015.

42. Fernandes, R.R.; Nunes, G.M.; Silva, T.S.F. Classificação orientada a objetos aplicada na caracterização da cobertura da terra no Araguaia. Pesqui. Agropecuária Bras. 2012, 47, 1251-1260. [CrossRef]

43. Definiens, T.G. Trimble eCognition Developer for Windows Operating System; 2018. Available online: https://www.geospatial. trimble.com/ecognition-download (accessed on 15 February 2022).

44. Baatz, M.; Schäpe, A. Multiresolution Segmentation—an optimization approach for high quality multi-scale image segmentation. In Angewandte Geographische Informationsverarbeitung XII; Strobl, J., Blaschke, T., Griesbner, G., Eds.; Wichmann, Verlag: Karlsruhe, Germany, 2000; pp. 12-23.

45. Yang, Z.; Willis, P.E.; Mueller, R. Impact of band-ratio enhanced awifs image to crop classification accuracy. Proc. Pecora 2008, 11, $1-11$.

46. Klock, U.; Muñiz, G.I.B.; de Hernandez, J.A.; Andrade, A.S. Química da Madeira. In Manual Didático: Curitiba, 3rd ed.; Revisada; Universidade Federal do Pará: Curitiba, Brazil, 2005.

47. Corpo de Bombeiros Militar. Manual Operacional de Bombeiros: Perícia de Incêndio; Corpo de Bombeiros Militar: Goiânia, Brazil, 2017; 276p

48. Landis, J.R.; Koch, G.G. The measurements of observer agreement for categorical data. Biometrics 1977, 33, 159-174. [CrossRef] [PubMed]

49. Hao, J.; Wan, S.; Li, Z.; Shao, Y.; Xu, G.; Liu, Z.; Zhou, L.; Fu, S. Dicranopteris-dominated understory as major driver of intensive forest ecosystem in humid subtropical and tropical region. Soil Biol. Biochem. 2012, 49, 78-87. [CrossRef]

50. Ramos, M.V.V.; Haridasan, M.; De Araújo, G.M. Caracterização dos Solos e da Estrutura Fitossociológica da Vegetação de Veredas da Chapada no Triângulo Mineiro. Front. J. Social, Technol. Environ. Sci. 2014, 3, 180. [CrossRef]

51. Moreira, S.N.; Pott, V.J.; Pott, A.; Da Silva, R.H.; Júnior, G.A.D. Flora and vegetation structure of vereda in southwestern cerrado. Oecologia Aust. 2019, 23, 776-798. [CrossRef]

52. Guimarães, A.J.M.; De Araújo, G.M.; Corrêa, G.F. Estrutura fitossociológica em área natural e antropizada de uma vereda em Uberlândia, MG. Acta Bot. Bras. 2002, 16, 317-329. [CrossRef]

53. Resende, I.L.D.M.; Dos Santos, F.P.; Chaves, L.J.; Nascimento, J.L.D. Estrutura etária de populações de Mauritia flexuosa L. F (Arecaceae) de veredas da região central de Goiás, Brasil. Rev. Árvore 2012, 36, 103-112. [CrossRef]

54. Marimon, B.S.; Lima, E.D.S.; Duarte, T.G.; Chieregatto, L.C.; Ratter, J.A. Observations on the vegetation of northeastern mato grosso, brazil. IV. An analysis of the cerrado-amazonian forest ecotone. Edinb. J. Bot. 2006, 63, 323-341. [CrossRef]

55. Miranda, I.S.; Almeida, S.S.; Dantas, P.J. Florística e estrutura de comunidades arbóreas em cerrados de Rondônia, Brasil. Acta Amaz. 2006, 36, 419-430. [CrossRef]

56. Valdés-Sáenz, M.A.; García-Quintana, Y.; Escarré-Esteve, A.; Flores, J.; Geada-López, G.; Arteaga-Crespo, Y.; Valdés-Sáenz, C.R. Estructura de un bosque natural perturbado de Pinus tropicalis Morelet en Galalón, Cuba. Bot. Sci. 2014, 92, 417. [CrossRef]

57. De Souza, C.R.; Rossi, L.M.B.; de Souza, C.R.; de Azevedo, C.P.; Yared, J.A.G. Taxi-Branco (Sclerolobium Paniculatum Vogel). In Manaus: Embrapa Amazônia Ocidental; Documentos 34; Manaus, Amazônia, Brazil, 2004; 23p, Available online: https://www. infoteca.cnptia.embrapa.br/bitstream/doc/675654/1/Doc34.pdf (accessed on 16 February 2020).

58. Pires, I.P.; Marcati, C.R. Anatomia e uso da madeira de duas variedades de Sclerolobium paniculatum Vog. do sul do Maranhão, Brasil. Acta Bot. Bras. 2005, 19, 669-678. [CrossRef]

59. Ávila, M.A.; Souza, S.R.; Veloso, M.D.D.M.; Santos, R.M.; Fernandes, L.A.; Nunes, Y.R.F. Structure of natural regeneration in relation to soil properties and disturbance in two swamp forests. Cerne 2016, 22, 1-10. [CrossRef]

60. Albor Pinto, C.; Tun Garrido, J.; Ortiz Díaz, J.J. Diversidad, estructura y afinidades florísticas de un bosque temporalmente inundable de la Península de Yucatán. Rev. Biol. Trop. 2017, 65, 68-880. [CrossRef]

61. Lorenzi, H. Árvores Brasileiras: Manual de Identificação e Cultivo de Plantas Arbóreas do Brasil, 5th ed.; Instituto Plantarum: Nova Odessa, Brazil, 2008; Volume 1.

62. Carvalho, P.E.R. Espécies arbóreas brasileiras. In Coleção Espécies Arbóreas Brasileiras, v. 1; Embrapa Informação Tecnológica: Brasília, Brazil; Embrapa Florestas: Colombo, Brazil, 2003; 1039p.

63. Araújo, G.M.; Barbosa, A.A.A.; Arantes, A.A.; Amaral, A.F. Composição florística de veredas no Município de Uberlândia, MG. Braz. J. Bot. 2002, 25, 475-493. [CrossRef]

64. Munhoz, C.B.R.; Felfili, J.M. Fitossociologia do estrato herbáceo-subarbustivo em campo limpo úmido no Brasil Central. Acta Bot. Bras. 2008, 22, 905-913. [CrossRef]

65. Townsend, C.; Begon, M.; Harper, J.L. Fundamentos em Ecologia, 3rd ed.; Artmed: Porto Alegre, Brazil, $2010 ;$ p. 576.

66. Miranda, S.C.; Carvalho, P.S.; Bustamante, M.M.C.; Silva Júnior, M.C. Variação temporal na estrutura da vegetação lenhosa de cerrado sentido restrito sobre Neossolos Quartzarênicos. Rev. Espac. 2017, 38 , 3.

67. da Silva, M.P.; Santana, N.C.; Guedes, S.R.A.; de Paula Laranja, R.E. Levantamento fitossociológico em ambiente de Vereda na apa ribeirões do gama e cabeça de veado, Brasília-DF. Rev. Geoaraguaia 2016, 6, 84-98.

68. dos Santos, H.G.; Jacomine, P.K.T.; dos Anjos, L.H.C.; De Oliveira, V.A.; Lumbreras, J.F.; Coelho, M.R.; De Almeida, J.A.; de Araujo Filho, J.C.; de Oliveira, J.D.; Cunha, T.J.F. Sistema Brasileiro de Classificação de Solos; Embrapa: Brasília, Brazil, 2018. 
69. Tarantino, E.; Figorito, B. Mapping Rural Areas with Widespread Plastic Covered Vineyards Using True Color Aerial Data. Remote Sens. 2012, 4, 1913-1928. [CrossRef]

70. Meneses, P.R.; de Almeida, T. Introdução ao Processamento de Imagens de Sensoriamento Remoto; UnB, CNPq: Brasília, Brazil, 2012; Available online: http:/ /www.cnpq.br/documents/10157/56b578c4-0fd5-4b9f-b82a-e9693e4f69d8 (accessed on 7 October 2020).

71. Queiroz, M.L. Nascentes, Veredas e Áreas Úmidas-Revisão Conceitual e Metodologia de Caracterização e Determinação: Estudo de caso na Estação Ecológica de Águas Emendadas_Distrito Federal. Master's Thesis, Universidade de Brasília, Distrito Federal, Brazil, 2015; 161p. [CrossRef]

72. Carvalho, A.C.A.; de Paula Laranja, R.E.; de Oliveira Nascimento, R.; Rodrigues, F.P. Delimitação e caracterização de um transecto na vertente do subsistema de vereda na reserva ecológica do IBGE/ RECOR-DF. Rev. Caminhos Geogr. 2018, 19, 233-249. [CrossRef]

73. Cunha, C.N.; da Piedade, M.T.F.; Junk, W.J. Classificação e Delineamento das Áreas Úmidas Brasileiras e de Seus Macrohabitats; EdUFMT: Cuiabá, Brazil, 2015; 165p.

74. De Pires, P.T.L.; Loper, A.A.; Mendes, C.J.; Peters, E.L.; Maia, G.N.; de Abreu, L.M. Dicionário de Termos Florestais; FUPEF: Curitiba, Brazil, 2018

75. Carvalho, P.E.R. Espécies arbóreas brasileiras. In Coleção Espécies Arbóreas Brasileiras, v. 2; Embrapa Informação Tecnológica: Brasília, Brazil; Embrapa Florestas: Colombo, Brazil, 2006; 627p, ISBN 85-7383-373-4.

76. Sartorelli, P.A.R.; Campos Filho, E.M. Guia de Plantas da Regeneração Natural do Cerrado e da Mata Atlântica; Agroicone: São Paulo, Brazil, 2017; Available online: https:/ /www.inputbrasil.org/wp-content/uploads/2017/05/INPUT_Agroicone_Guia-dePlantas-da-Regeneracao-Natural-do-Cerrado-e-da-Mata-Atlantica.pdf (accessed on 18 February 2020).

77. Hoffmann, W.A. Post-Establishment Seedling Success in the Brazilian Cerrado: A Comparison of Savanna and Forest Species1. Biotropica 2000, 32, 62-69. [CrossRef]

78. Hoffmann, W.A. Fire and population dynamics of woody plants in a neotropical savanna: Matrix model projections. Ecology 1999 80, 1354-1369. [CrossRef]

79. Ribeiro, G.A. Estudos do Comportamento do Fogo e de Alguns Efeitos da Queima Controlada em Povoamentos de Eucalyptus Viminalis Labil em Três Barras. Ph.D. Thesis, Universidade Federal do Paraná, Curitiba, Brazil, 1997.

80. Myers, R. Convivendo Com o Fogo: Manutenção dos Ecossistemas E Subsistência com o Manejo Integrado do Fogo; The Nature Conservancy: Tallahassee, FL, USA, 2006.

81. Couto, E.G.; Chig, L.A.; Cunha, C.D.; Loureiro, M.D.F. Conhecendo o Pantanal 2: Estudo Sobre o Impacto do Fogo na Disponibilidade de Nutrientes, no Banco de Sementes e na Biota de Solos da RPPN SESC Pantanal; Serviço Social do Comércio: Rio de Janeiro, Brazil, 2006; 56p.

82. Matos, D.M.S.; Pivello, V.R. O impacto das plantas invasoras nos recursos naturais de ambientes terrestres-Alguns casos brasileiros. Cienc. Cult. 2009, 61, 21-30.

83. Henriques, R.P.B.; Hay, J.D. Patterns and Dynamics of Plant Populations. In The Cerrados of Brazil: Ecology and Natural History of a Neotropical Savana; Oliveira, P.S., Marquis, R.J., Eds.; Columbia University Press: New York, NY, USA, 2002.

84. Fank-de-Carvalho, S.M.; Báo, S.N.; Marchioretto, M.S. Amaranthaceae as a Bioindicator of Neotropical Savannah Diversity. In Biodiversity Enrichment in a Diverse World; IntechOpen: London, UK, 2012; pp. 235-262. [CrossRef]

85. Silva, D.M.; de Paula Loiola, P.; Rosatti, N.B.; Silva, I.A.; Cianciaruso, M.V.; Batalha, M.A. Os efeitos dos regimes de fogo sobre a vegetação de cerrado no parque nacional das emas, GO: Considerações para a conservação da diversidade. Biodivers. Bras. 2011, 2, 26-39. [CrossRef]

86. Montoya, E.; Rull, V.; Nogué, S.; Diaz, W.A. Paleoecología del Holoceno en la Gran Sabana, SE Venezuela: Análisis preliminar de polen y microcarbones en la Laguna Encantada. Collect. Bot. 2009, 28, 65-79. [CrossRef]

87. Montoya, E.; Rull, V.; Stansell, N.; Abbott, M.B.; Nogué, S.; Bird, B.W.; Díaz, W.A. Forest-savanna-morichal dynamics in relation to fire and human occupation in the southern Gran Sabana (SE Venezuela) during the last millennia. Quat. Res. 2011, 76, 335-344. [CrossRef]

88. Campos, J.M.S.; Davide, L.C.; Soares, G.L.G.; Viccini, L.F. Mutagenic effects due to allelopathic action of fern (Gleicheniaceae) extracts. Allelopath. J. 2008, 22, 143-151.

89. de Werneck, M.S. Conservação da Flora e Planejamento Ambiental no Contexto da Expansão Urbana da Região Metropolitana de Belo Horizonte, Minas Gerais. Ph.D. Thesis, Universidade Federal de Minas Gerais, Belo Horizonte, Brazil, 2006.

90. de Paula Athayde Filho, F.; Agostinho, A.A. Pteridoflora de duas Veredas no Município de Campinápolis, Mato Grosso, Brasil; Pesquisas, Botânica. N 56: 145-160; Instituto Anchietano de Pesquisas: São Leopoldo, Brazil, 2005.

91. Gonçalves, J.R.; Ferreira, J.F.R. Pteridófitas: Uma investigação de táxons na vereda do córrego Mogi no município de UberlândiaMG. E-RAC 2012, 2, 1-17.

92. BRASIL. Resolução n 7, De 29 De Maio De 2018. Brasília, DF, Mai 2018. Available online: http:/ /www.institutohorus.org.br/ download/marcos_legais/Resolucao_CONABIO\%2007\%20-\%202018.pdf (accessed on 15 February 2022).

93. BRASIL. Decreto n ${ }^{\circ}$ 2.519, De 16 De Março De 1998. Brasília, DF, Mar. 1998. Available online: http:/ / www.planalto.gov.br/ccivil_ 03/decreto/d2519.htm (accessed on 15 February 2022).

94. ICMBIO; MMA. Guia de Orientação para o Manejo de Espécies Exóticas Invasoras em Unidades de Conservação Federais. 2019. Available online: https://www.icmbio.gov.br/cbc/images/stories/Publica\%C3\%A7\%C3\%B5es/EEI/Guia_de_Manejo_de_EEI_ em_UC_v3.pdf (accessed on 18 February 2020). 
95. Carvajal-Ramírez, F.; Marques da Silva, J.R.; Agüera-Vega, F.; Martínez-Carricondo, P.; Serrano, J.; Moral, F.J. Evaluation of Fire Severity Indices Based on Pre- and Post-Fire Multispectral Imagery Sensed from UAV. Remote Sens. 2019, 11, 993. [CrossRef]

96. McKenna, P.; Erskine, P.D.; Lechner, A.M.; Phinn, S. Measuring fire severity using UAV imagery in semi-arid central Queensland, Australia. Int. J. Remote Sens. 2017, 38, 4244-4264. [CrossRef] 